\title{
The problems of the ethnogenesis and relocation of akhis turks in Kazakhstan
}

\author{
DOI: 10.31551/2410-2725-2019-5-2-177-196
}

\section{Kudaibergenova Ayzhamal Ibragimovna}

Chief Researcher at the Institute of History and Ethnology named after Ch.Ch. Valikhanov, Doctor of Historical Sciences, Republic of Kazakhstan, Almaty. E-mail: akudaybergen@mail.ru

\section{Kupenova Zhuldyz Kaiyrbekkyzy}

Master of Social science, lecturer at accounting and audit department in al-Farabi Kazakh National University Kazakhstan, Almaty. E-mail: ms.kupenova@mail.ru

\begin{abstract}
The article considers the issue of ethnogenesis and the history of the emergence of Ahiska Turks in Kazakhstan based on documentary sources and memories. The authors emphasize that the Turks represented in the Russian and Georgian studies as «Meskhetians» or "Meskhetian Turks» are part of the descendants of the Ahiska Pashalyk Turks. In the article, the authors note that the Ahiska Turks are descendants of the Huns, even descended before the Huns from the ancient Proto-Türks, who migrated in the 2nd century to the north of the Caucasus from Central Asia. The article also discusses the history of their deportation to Kazakhstan in the $1940 \mathrm{~s}$.

Before being expelled, the Turks were offered to register as Georgians or Azerbaijanis. Among them some people signed registered themselves as Georgian, Azerbaijani or Turkmen in order to save their family and offspring. But, as Georgian researchers note, the brave people showed resistance. Despite the repression, the Ahiska Turks were able to preserve their originality, loyalty and nobility.

After rehabilitation in 1956, many special settlers returned to the Caucasus. After the collapse of the USSR, most of the deportees returned to their historic homeland. Only Ahiska-Turks were not destined to return to their ancestral lands. Georgia did not accept them, and Turkey is not their historic homeland. Thus, Kazakhstan became the second small Homelandfor them. At the present time about 200 thousand Ahiska-Turkslive in Kazakhstan. In addition to them, it is believed that out of 115,000 Azerbaijanis, 80 percent can be Turks. Two siblings live in one family: one of them is recorded as Azerbaijani, and the second is Turk. Thus, historical justice is gradually restored in relation to those Turks who had to become representatives of other ethnic groups. The unity of the Turks in Kazakhstan is manifested in the preservation of their ethnic language, original culture and national tradition.
\end{abstract}

Keywords: Kazakhstan, Georgia, Turkey, Meskhetian Turks, Ahiska Pashalyk, Ahiska Turks, deportation, special settlers.

\section{Ахыска түріктерінің этногенезі мен Қазақстанға жер аудару мәселесіне орай}

\section{Құдайбергенова Айжамал Ибрагимқызы}

Тарих ғылымдарының докторы, доцент, Ш.Ш. Уәлиханов атындағы Тарих және этнология институты, Қазақстан Республикасы, Алматы қ. E-mail: akudaybergen@mail.ru

\section{Купенова Жұлдыз Қайырбекқызы}

Әлеуметтік ғылымдар магистрі, Есеп және аудит кафедрасының оқытушысы, әл-Фараби атындағы ҚазҰУ Қазақстан Республикасы, Алматы қ. E-mail: ms.kupenova@mail.ru Аңдатпа: Мақалада қазақстандық түріктердің этникалық негізі мен Қазақстанға келуінің тарихы
құжаттар мен естеліктер негізінде тереңдете қарастырылады. Ресейлік зерттеушілер еңбектері
мен грузиндік зерттеулерде «түрік-месхеттер» деп аталып жүрген ахыска түріктерінің Ахыска
пашалығында өмір сүрген түріктердің ұрпақтары тобынан екеніне назар аударылады. Ахыска
түріктеріІІ ғасырда Кавказдың солтүстігіне Орталық Азиядан қоныс аударған түркі тайпалары -
ғұндардың, тіпті ғұндарға дейінгі ежелгі прототүркілердің ұрпақтары деп тарқата келе, авторлар
Грузияның Месхетия, Жавахетия аймағын мекендеген түріктердің XX ғ. 40-жж. Қазақстанға жер
аударылу тарихына да тоқталады. Жер аудару алдында түріктерге грузин не азербайжан болып
жазылыңдар деген ұсыныстар айтылады. Отбасын, ұрпағын сақтап қалу үшін арасында грузин,
азербайжан, түрікмен болып жазылғандар да кездесті. Бірақ, ер халық репрессияға
ұшырағанымен, өздерінің тегін, түп негізін, адалдығын сақтап қалғандар негізгі көпшілік болды.
1956 ж. жер аударылғандардың біразы Кавказға қайта оралды. Кеңестер Одағы тарағаннан кейін
де депортацияланған халықтардың көбі өздерінің тарихи отанына оралды. Ал, түріктер қайта
алмады. Туған жері Грузия шекарасы олар үшін жабық болды, ал Түркия Ахыска түріктерінің
туған отаны емес. Осылайша, Қазақстан ахыска түріктері үшін-Кіші Отан. Қазір Қазақстанда 200
мыңдай түрік тұрады. Одан бөлек 115 мың азербайжанның 80\%-ын да түріктер деп айтуға 
болады делінеді. Тіпті бірінің ұлты түрік, екіншісі - «әзірбайжан» болған бірге туған екі бауырды кездестіруге болады. Тоталитарлық билік адамдардың өткенін, түп-тамырын ұмытуы үшін бәрін жасады. Бірақ түріктердің ынтымағының арқасында олар тілін, өз мәдениеті мен ұлттық дәстүрлерін сақтай алды.

Кілт сөздер: Қазақстан, Грузия, Түркия, түрік-месхеттер, Ахыска пашалығы, ахыска түріктері, депортация, арнайы қоныстанғандар

\section{К проблеме этногенеза и депортации ахыска-турков в Казахстан}

\section{Кудайбергенова Айжамал Ибрагимовна}

доктор исторических наук, доцент. Институт истории и этнологии им. Ч.Ч. Валиханова. Казахстан, г. Алматы. E-mail: akudaybergen@mail.ru

Купенова Жулдыз Кайырбековна

Магистр социальных наук, преподаватель кафедры учет и аудит Казахского национального университета им. аль ФарабиКазахстан, г. Алматы. E-mail: ms.kupenova@mail.ru

Аннотация. В статье на основе документальных источников и воспоминании рассматривается проблема этногенеза и истории появления в Казахстане турков-ахыска. Авторы акцентируют внимание на то, что турки, представленные в российских и грузинских исследованиях «месхетинцами» или "турками-месхетами» являются частью потомков турков Ахыскиского пашалык. В статье авторы отмечают, что турки-ахыска являются потомками гуннов, даже произошли до гуннов от древних прототурков, которые мигрировали во II в. на север Кавказа из Центральной Азии. В статье также рассматривается история их депортации в Казахстан в 40-гг. XX B.

Перед высылкой туркам было предложено записаться грузинами или азербайжанцами. Среди них встречались и те кто записался грузином, азербайжанцем или туркменом ради спасения семьи и потомства. Но храбрый народ проявил сопротивление. Несмотря на то что был подвержен репрессии смог сохранить свою самобытность, преданность и знатность.

После реабилитации 1956 г. многие спецпереселенцы вернулись на Кавказ. После развала СССР на историческую родину вернулись большинство депортированных народов. Только ахыска-турки не смогли возвращаться на свои исконные земли. Грузия не принимала, а Турция не является их исторической Родиной. Таким образом, Казахстан стал для них второй малой Родиной. Сейчас в Казахстане живут около 200 тысяч ахыска-турков. Кроме них, считается что из 115 тысяч азербайжанцев 80 процентов могут быт турками. В одной семье живут два родных братья: один из них записан азербайжанцем, а второй турком. Таким образом, сами турки восстанавливают историческую справедливость в отношении той части, которым пришлось стать представителем других этносов. Единство турков в Казахстане проявляется в сохранении своего этнического языка, самобытной культуры и национальной традиции.

Ключевые слова: Казахстан, Грузия, Туркия, турки-месхетинцы, Ахыскинский пашалык, ахыска турки, депортация, спецпереселенцы.

\section{ӘОЖ/UDC 94(574/575)}

\section{Ахыска түріктерінің этногенезі мен Қазақстанға жер аудару мәселесіне орай}

\section{А.И. Кудайбергенова, Ж.К. Купенова}

Кіріспе. Адамзат пен тарихтың қоғам дамуындағы өзара байланысына қатысты: «Бүгінгі күнді түсініп-түйсіну - өткен тарихты білу, ал, өткен тарихты білу - болашақты меңгеру» - деген ұғым бар. Қазақстандықтардың бүгінгі күні ынтымақтастықта, болашақта біртұтастықта өмір сүру үшін өткен тарихының шынайы бейнесін анықтау қажеттілік болып табылады.

Бүгінде Қазақстанды тілі, діні, ділі басқа болғанымен, тілегі, теңдігі бір 127 ұлт пен этнос өкілдері мекендейді. «Бір мақсат, бір мүдде, бір болашақ» үшін «бір жағадан бас, бір жеңнен қол шығарып», қиындықтарға төтеп, 
жетістіктерге жету жолында бірлесе өмір сүрудегі қазақстандықтар ішінде айрықша орынды түркі халықтары алады.

Түркі халықтары - құрамында ассимиляцияға ұшыраған әртүрлі этностардың болғанына қарамастан этномәдени жағынан ұқсас деп айтуға болатын, түркі тілінің бірінде сөйлейтін туыстас халықтар. Адамзат өміріндегі ірі соғыстарға, көші-қондарға, Азия мен Европада мемлекеттік құрылымдардың пайда болуына байланысты орын алған өзгерістердің нәтижесінде әлемде түркі халықтарының біріне жататын, түркі тілдерінің бірінде сөйлейтін ұлттар мен этностар пайда болды. Түркілер әлемдік тарихта мықты әскер, мемлекеттер мен империялардың негізін қалаушы, шебер малшылар ретінде танымал. Джавахарлал Неру өзінің «Әлем тарихына көзқарас» еңбегінде түркілердің рөлі туралы: «Олар Азияның әскери мақтанышы болды» деп баға берген екен.

Орта ғасырларда Азиядағы әскери күш мен мықтылықтың символы болған түркі халықтары XIX-XX ғасырларға қарай билеуші мәртебесінен толықтай айрылып, ұлы империялардың отарлары мен жартылай отарларына айналды. Ресей мемлекеті ғасырлар бойы түркі халықтары мекендеген, түркі мемлекеттері өмір сүрген бірқатар аумақты күшпен өз қоластына ендіргеннен бері түркі халықтарын дезинтеграциялау мен ассимиляциялау саясатын жүргізді. Сондықтан, XX ғ. басына қарай түркі әлемінде өзін-өзі тану мен этникалық біртұтастыққа қарай ұмтылыс орын алды. Түркішілдік идеясы пайда болып, дамыды. Бұл идея бір-бірінен бөлек болса да әртүрлі түркі халықтарында ұлттық сананы қалпына келтіру, бостандыққа жету және мәдени дамуды жандандыру тұрғысынан көрінді. Бірақ, XX ғ. басы мен ортасында тоталитарлық жүйенің қуғынының арқасында түркішілдік қысым көріп, идея түрінде күйреді. Осы дәуірде түркішілдік идеясы мен түркі халықтарының дамуына деген саясат ұқсас болды. Түркішілдікке қарсы тойтарыс түркі халықтарының жақындасу идеясына да нұқсан келтірді. Түркішілдік идеяны ұстанған басшылар ғана емес, тұтастай түркі халықтары тепкіріш көре бастады. Тұтастай халықтар қуғын-сүргінге ұшырады.

Бұл үдеріс түркі халықтарының бірлігіне, тұтастығына селкеу түсіріп, бөлшектеу, бөлектеу үрдісінің сыналап еніп, тұрақтылыққа айналуына әкелуі керек еді. Тіпті түркі халықтарының ұқсастықтары мен түбі бірлігін ұмыттыру қаупі туды.

XIX ғ. соңында Қазақстанда түркі халықтары негізгі көпшілік болды. Ал, XX ғ. тарихи оқиғалар славян типтес халықтардың үлесін өсіріп, түркі халықтары өкілдерінің кему үрдісін күшейтті.XXI ғ. басында жағдай өзгерді: түркі халықтарының үлесі өсті. Қазіргі кезде 18 миллионнан асқан қазақстандықтардың құрамында түркі халықтарына жататын 25 этностың өкілдері өмір сүреді: қазақтар, өзбектер, татарлар, қырғыздар, қарақалпақтар, түрікмендер, башқұрттар, ұйғырлар, түріктер, әзірбайжандар, чуваштар, балкарлар, қарашайлар, қырым татарлары, ноғайлар, құмықтар, гагауыздар, сахалар, алтайлықтар, хакастар, т.б. Солардың ішінде өзінің тарихи тағдырында түркі халықтарына деген тоталитарлық жүйенің қысымын кеңінен татқан ахыскалық түрік ағайындардың тарихын тереңдету өзектілігін жоғалтпаған тақырып болып табылады.

\section{Материалдар мен әдістер}

Деректер ретінде архив құжаттары(қазақстандық және ресейлік), құжаттар жинақтарындағы мәліметтер: «Из истории депортации народов в Алматинскую область Казахстана» (Из истории, 2010), «Из истории депортаций в Казахстан. 1930-1935» (Из истории, 2012). «Иосиф Сталин - Лаврентию 
Берия: «Их надо депортировать...» (Иосиф, 1992), «Саяси жазалауға ұшыраудың құрбаны болғандардың жазасын ақтау және жазалауға ұшырау туралы заң шығарушы және ереже актілерінің жинағы», «Депортированные в Казахстан народы: время и судьбы» (Депортированные, 1998), «Сталинские депортации 1928-1953 гг.» (Сталинские, 2005), т.б. қолданылды.

Қазақстандағы түріктердің XIX ғ. соңынан бастап Қазақстан жерінде болғанын және негізгі бөлігінің 1944 ж. қарашасы мен желтоқсаны арасындағы депортация кезінде Грузиядан жер аударылған ахыска түріктері екендігі, Қазақстандағы түріктердің Түркиядан, Грузиядан және Азербайжаннан келгендіктері нақтыланды.

Түрік диаспорасы шоғырланған Қазақстанның оңтүстігіндегі Алматы, Жамбыл, Оңтүстік Қазақстан және Қызылорда облыстарында ахыска түріктерінің өкілдерінен сұхбат алынды. Мысалы, Алматы облысының Қаратал ауданы Балпық би ауылында тұратын Қамбар Мұстафраев Маметұлы түп атасының Түркиядан Азербайжанға XX ғ. басындағы соғыс кезінде келгенін, әкесінің 1915 ж. Түрік армиясында әскери қызмет атқарғандығын, Азербайжанға келіп, отбасын құрып қалып қойғандығын, өздерінің Қазақстанға Азербайжаннан келгендерін және өздерінің түрік болып жазыла алмаған себептерін ашты. Кеңестік кезеңдегі түрік ұлтына деген әділетсіз көзқарас арқасында азербайжан деп жазылуға мәжбүр болғандықтарын атап көрсетіп, Қазақстанға келгеннен кейінгі күнделікті өмір тарихынан да сыр шертті. Сондай-ақ, Алматы облысы Еңбекшіқазақ ауданының тұрғыны Раджабова Зульфия Исламқызымен, Агададиев Асанпашамен, Көксу ауданы Белбұлақ ауылының тұрғыны Тутадзе Хайриддин Каримовичпен, «Ахыска» түрік этно-мәдени орталығының төраға орынбасары Асиев Шахисмайл Ахметұлымен, Қарасай ауданынан Мамедов Руслан Шавкетовичпен және т.б. сұхбаттар Қазақстандағы түріктердің тарихына қатысты мәліметтер алуға көмектесті. Мысалы, фрамилиясы грузинше Тутадзе, өзі түрік, ал паспортта азербайжан болып жазылған Хайриддин Каримұлы өзінің аталары Османдар әулетінен тарағандығын, Түркиядан КСРО-ға келуінің себептерін, өмір тарихын тарқата отырып, түрік этносы басынан өткізген қиын-қыстау кезеңдерден бірқатар

сыр шертті.

Талқылау: Түріктер тарихын зерттеушілердің алғашқыларының қатарына қырғыздың белгілі жазушысы Шыңғыс Айтматовты жатқызуға болады. Ол «Негіздері шайқалды ма?» мақаласында: «...Думаю, что и полпотовцы, учинившие невиданный геноцид собственного народа, имели в этом смысле достаточно прозрачный пример (стоит вспомнить историю истребительного сталинского переселения к концу войны чеченцев, ингушей, калмыков, карачаевцев, кавказских турок-месхетинцев, курдов, крымских татар, немцев Поволжья. До сих пор... тянется шлейф тех бед и страданий!» деп жазған болатын.

Түрік халқынан шыққан ғалым-дәрігер Т.А. Курдаев қуғындалып келген түріктердің ішінде келген ол сәби кезінде-ақ көрген-білгенін, көкірегіне түйгенін, үлкендерден естігенін жинақтап, өз ұлтының тарихи тағдырына қатысты еңбек шығарған (Курдаев, 1996).

Ахыска түріктері мәселесі Түркия Республикасы, Кавказ елдері ғалымдары тарапынан біршама зерттелген. Ондай еңбектердің қатарына М.3. Закиевтің «Глубокие этническое корни тюркских народов» (Закиев, 2011), А. Гаджиевтің «На чужбине. Этническая культура ахалцихских (месхетинских) турок» (Гаджиев, 1992),В.А. Симоненконың «Месхетинские турки: историческая судьба 
и проблемы культурной адаптации» (Симоненко, 2002), «Тюркские народы Сибири» (Симоненко, 2010), Velidi A.Z. Bügüngü Türkili (Türkistan) ve yakin tarihi (Velidi, 1981), «Материалы по этнической истории тюркских народов Центральной Азии», т.б. жатқызамыз (Материалы, 2003).

Сондай-ақ, Қазақстанда тұратын түріктер туралы жазылған Паин Эмильдің «Халық транссрері: месхет түріктерінің қасіреті» атты (Population transfer: the tragedy of Meskhetian Turks) мақаласында (Пайн, www.culturalsurvival.org) Грузиядан түрік-месхеттердіं Орталық Азия елдеріне депортациялау жайлы жазады. Автор грузиндердің және түріктердің өздерінің пікірлеріне орай месхеттердің этникалық құрамын талдайды. Депортацияның діни, сыртқы саяси, қауіпсіздік мәселесіне қатысты себептерін қарастырады. Автор грузиндер мен месхет түріктерінің пікірлерін келтіре отырып, түріктердің этностық жағдайын талдайды.

Анкаралық зерттеуші Айшегюль Айдынгюн «Ахыска түріктері. Трансұлттық қауымдастық, трансұлттық отбасылар» (Aydıngün, 2014) және т.б. кітаптары әлемнің әр түрлі елдерінде шашырай орналасқан ахыскалар мен олардың отбасылары туралы әлеуметтанушылық зерттеу болып табылады. Автор еңбегінде ахыска түріктерінің тарихын зерттей отырып, олардың шығу тегі жайлы әртүрлі көзқарастарды бөліп көрсетеді. Айшегюль Айдынгюнның пікірі бойынша ресейлік және грузиндік зерттеушілердің еңбектерінде саяси мән араласқан. Грузиндік зерттеушілердің пікірінше, бұл халық кезінде христиан дінінде болған, кейін мұсылмандықты қабылдаған грузиндер болып табылады. Басқа сөзбен айтқанда, кейіннен түріктенген мұсылман-грузиндер деп көрсетеді.

Ресейлік зерттеулер ахыска түріктерін б.з.д. 2 ғасырда қыпшақтар мен қарапапахтармен бірге өмір сүрген кавказдық булгарлармен байланыстырады. Тағы бір болжам бойынша ахыска түріктері түркіленген грузиндер мен түріктердің араласуынан пайда болған халық болып табылады.

Үшінші, түріктік деректерде кездесетін көзқарас бойынша, олар қыпшақтардың тікелей ұрпағы. Осман билігінің ұзақ уақыт үстемдік етуі жаңа түркі халықтарының қалыптасуына әкелді. Ахыскалық түріктер солардың бірі.

Айшегюль Айдынгюн ахыска түріктерінің құрамына қыпшақтарды, түрікмендерді, анатолийлік түріктерді және түркілеген грузиндерді қосқанда олардың араласуынан пайда болған біріккен құрылым болуы керек деген тұжырымдайды. Автордың айтуынша, «ахыска» этнонимі XX ғасырдың 80 жылдары пайда болды және бұл ұғымның ішінде түріктер, түркмендер, аз санды күрдтер мен Месхетия-Джавахетияның мұсылман грузиндері кіреді (Aydıngün, 2014)

Висконсия университетінің антропология профессоры А.М. Хазанов өзінің «Месхет түріктері: өзіндік біртұтастықтарын іздеу жолында» (Месхетинские турки в поисках самоидентичности (Meskhetian turksin search of self-identity) (Khazanov, 1992) мақаласында осы күнге дейін не ұлттық, не аймақтық, не азаматтық біртұтастығына ие болмаған ахыскалық түріктердің (мақалада түрікмесхеттер) мәселелерін қарастырады. Ол Грузияның мұсылмандықты қабылдаған, тағдырлары басқаша қалыптасқан екі халық - аджарлар мен түріктерді салыстырып, аджарлар мен ахыска түріктерін түркіленген грузиндер мен түріктердің араласуынан пайда болған халық деген пікір айтады. Оның пайымдауынша, аджарлар ислам дінін қабылдағанымен, тілдерін ғана емес, грузиндік дәстүрлі мәдениетті де сақтап қалды, ал месхеттік түріктер түркі тілі 
мен түріктіердің дәстүрлі мәдениетін жоғалтпаған. Месхетиялық түріктердің қалыптасуында түркі халықтарының орны ерекше маңызды болғандықтан олардың қалыптасу жағдайы күрделірек болған (Khazanov, 1992). Ол ахыскалық түріктерді осыдан отыз жыл бұрынғы жағдайы қалай болса, әлі де сондай, әлі күнге дейін қудаланып жүрген және келуі құпталынбайтын этникалық азшылық деп ой түйеді.

Ғылыми әдебиетте аталмыш тақырыпты талдау этностар, диаспоралар тарихын зерттеумен байланысты. Қазақстандық тарих ғылымында Ахыска түріктерінің тарихы мен демографриялық даму бойынша арнайы зерттеулер жоқ. Тек, Ш.О. Ибрашеваның «Қазақстандағы ахыска түріктері» монографиясын ахыскалық түріктердің этномәдени даму тарихын зерттеген алғашқы еңбек қатарына жатқызамыз (Ибрашева, 2014). Бірақ, монографияның басты назарында Ахыска түріктерінің этномәдени және этнотілдік үрдістері, неке мен отбасы құрамы, туысқандық қарым-қатынас, некелесу түрлері мен бала тәрбиесі, үйлену мен жерлеуге қатысты әдет-ғұрыптарды зерттеу болғандықтан, еңбекті этнографиялық және этносоциологиялық бағыттағы жұмыстардың қатарына жатқызамыз. Ал, жоғарыда көрсетілген әдебиеттер, негізінен, өзге мемлекеттердегі түріктердің тағдырын да қарастырады.

Э.Х. Панеш пен Л.Б. Ермолов түріктердің этникалық тарихы мен этногенезіне едәуір көңіл бөлген. Олар осы мәселеге байланысты зерттеушілердің қарама-қарсы екі бағытын көрсеткен. Бірінші ғалымдар тобы, грузин деректеріне сүйеніп, түріктерді бұрын грузин-түрік шекаралық аудандарында тұрған - «грузин-месхлер» деп есептейтіндер. Бұл месхетия халқы «грузиндік сана-сезімін жойған және исламды қабылдағандар» деп жазады. Ал, екінші топ оларды түріктердің тегімен байланыстырады. Сонымен қатар, Э.Х. Панеш және Л.Б. Ермолов 1944 ж. Орта Азияға негізгі көрсеткіш бойынша 115,5 мың түріктің Өзбекстанға, Қазақстанға және Қырғызстанға депортациялануы барысында түріктердің басынан кешкен ауыр зардаптарына қысқаша тоқталып, тұрғылықты халықпен қоғамдық ортада ұзақ уақыт бойы бірге өмір сүру нәтижесінде, түрік диаспорасының өкілдері өздерінің ұлттық, дәстүрлік мәдениетін ұмыта бастады деп атап көрсетеді (Панеш, 1991).

Жер аударылған этнос өкілдері туралы, арнайы қоныс аударылғандар мәнмағынасын ұғындыратын мәліметтері мол тұңғыш рет жарияланған еңбек деп В.Н. Земсковтың мақаласын атап кетейік (Земсков, 1990).

А.Б. Айдынгюннің «Депортацияға ұшыраған ұлт: ахыска түріктері» (А deported nationality: the ahiska turks) атты мақаласында (Aydıngün, 1998-1999) кеңестік саясаттың салдарынан өз отанынан көшуге мәжбүр болған месхет түріктерінің КСРО ыдырағаннан кейінгі жағдайы баяндалады. Автор саяси, гуманитарлық, территориялық құқықтарына, өздерінің этностық бірегейліктерін сақтау жолдары мен аталмыш проблеманың саяси стратегиялық бағытына мән береді. Еңбекте месхеттердің депортациясы, олардың Орта Азия мемлекеттеріне орналастырылуы депортацияланған халықтар мен жергілікті халықтар арасында туындаған этносаралық қақтығыстар тарихы қарастырылады. Айшегюль Айдынгюн халықтарды жаппай жер аудару сценарийі жаңа халықтардың қалыптасуында катализатор рөлін ойнады деп ой түйеді.

Н.Ф. Бугайдың құрастыруымен шыққан «Турки из Месхетии: долгий путь реабилитации» атты құжаттар жинағы шықты (Бугай, 1994).

ТМД түріктерінің ауыр тағдырына Т.А. Курдаевтың (Курдаев, 1996), 1944 ж. күштеп депортациялауға Қ.С. Алдажұманов және Е.Қ. Алдажұмановтың (Алдажуманов, 1998), Ғ. Анестің (Анес, 1998), О. Дымовтың (Дымов, 1998), А. 
Юнусовтың (Юнусов, 1999), т.б. еңбектері арналды. А. Юнусовтың «Ахыскинские (месхетинские) турки: дважды депортированный народ» атты еңбегінде ахыска түріктерінің этногенезі туралы мәселе қозғалады. Автор онда «ахыскалық түріктер» терминін қолданады. Ахыска түріктерінің даму кезеңін II ғ. бастап XX ғ. дейін төртке бөледі. Сондай-ақ, ахыска түріктерінің тегі түріктер, басқаша атауы «ахыска түріктері» деп дәлелдейді (Юнусов, 1999).

Сонымен, депортация тақырыбына қатысты жарияланған еңбектерде қуғын сүргінге ұшыраған этностардың тарихы және жергілікті өмірге бейімделуі куәгерлердің естеліктерімен толықтырыла отырып зерттелгенімен, ахыскатүріктердің ерекшеліктері терең көрсетілмеген.

Нәтижесі. Түрік диаспорасы - әлемдегі ірі этникалық қауымдастық. Соның ішінде ахыскалық түріктер (этностың бірнеше синонимді атаулары бар: өзіндік

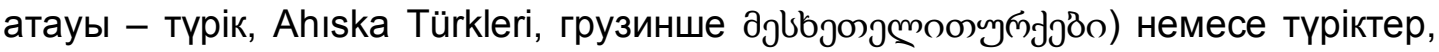
ахыскалар, түрік-ахыскалар, түрік-хемшилдер, түркі-джавахтар, осман түріктері, ахалцих түріктері, ахалцих түркілері, ахыска-түріктер, кавказдық түріктер Грузияның Оңтүстік-Батысынан, Түркиямен шекаралас бөлігі МесхетияЖавахетия аймағынан шыққан түріктердің тобы.

Ахыска түріктері ТМД мемлекеттерін мекендеген түрік этностарының ішіндегі негізгі және Грузия мен Түркия территорияларының шекаралық аймағында қалыптасқан этникалық топ болып табылады. Кейбір критерийлер бойынша бұл этнос түрік үстемдігін құрайтындардың мәдени ерекшелігін қамти отырып, түрік тілінің шығыс-анатолиялық диалектісі мен түріктік мәдениеттің негізінің болғанын дәлелдейді. Айта кету керек, осы тәрізді екіжақты этномәдени бастауының анық сипатталуымен көрінетін маргиналды этнографриялық топтар этногенетикалық фракторлардың басымдығымен әлемнің шекаралас аймақтарына кең тараған құбылыс.

Ал «ахыска» сөзі нені білдіреді? Оның шығу тегі қандай? Неге қазақстандық түріктер өздерін «ахыска түріктері» деп атағанды дұрыс деп есептейді? Міне осыны анықтайық.

Месхетия, Жавахетияны мекендеген түріктердің ескі тарихы мен этногенезі үздіксіз пікірталастардың туындауына түрткі болды. Кейбіреулер грузиндік шығу-тегін сақтап қалу үшін бұл этносты өзіндік халықтық мінез-ерекшелігінен, мәдениеті мен тілінен ажырата отырып, географиялық атауына қарай месхеттер деп атады. Бірқатары месхеттік түріктерді «түркіленбеген грузиндер» деп есептеді, ал түріктердің бұған қарсы дәлел ретінде келтіретіндері осы этностың жалпы түркілік антропологиялық, мәдени, тілдік ұқсастықтарының болуы мен Шығыс түрік Анатолының Грузияның оңтүстікбатысындағы Месхетиямен шекараластығы - тарихи Отанының бірлігі. Бұл халықтың «ахыска түріктері» деп аталуының өзі түрік тілінен аударғанда «ахалицихе түріктері» тіркесінің әкімшілік орталық атауының түрік нұсқасынан шыққандығынан деп көрсетеді.

Қазақстандық түріктер өздерінің түпкі шыққан тегін түріктермен, ал әкімшілік территориялық бірлігін Түркияның саяси мемлекеттік құрылымының құрамында болған Ахыска пашалығымен байланыстырады. Сол арқылы өздерінің грузиндік емес түркиялық негізін көрсетеді.

XVI ғасырда Түркия билігіндегі Ахыска пашалығын, ал 1829 ж. Ресей Империясы өзіне қосып алған Месхетияның бір бөлігін мекендеген ахыска түріктерінің тарихы Кавказ өңіріне түркі тайпаларының таралуынан бастау алады. Ахыска түріктеріІl ғасырда Кавказдың солтүстігіне Орталық Азиядан қоныс аударған түркі тайпалары - ғұндардың, тіпті ғұндарға дейінгі ежелгі прототүркілердің ұрпақтары. 
Грузия жерін XI ғасырда Орта Азия және Қазақстаннан түркілердің екінші толқыны - оғыз және қыпшақ тайпалары мекен етті. XIV ғасырдан бұл жерлер Осман империясының құрамына еніп, Ахыска пашалығы құрылған. Ахыска пашалығының халқы: II ғасырда басталған месхтардың грузиндік және түріктердің тайпаларының Азия мен Кавказ өңірінде жаппай пайда болуына қатысты екі негізгі компоненттен тұрды. Месхет жотасы аймағы грузин патшалары мен түрік сұлтандарының билік ету аясын бөліп тұратын шекаралық аймаққа айналды. 1555 ж. Самцхе-Саатабагон Осман империясы құрамына енгеннен кейін Месхетия аймағы түрік этносының әсер ететін аумағында қалып, Ахыска патшалығы деп аталды. XIX ғасырдағы орыс-түрік соғысынан кейін 1829 ж. келісімшарт бойынша Осман империясының солтүстікшығысындағы бірнеше аймақтар - Ахалцих және Ахалкалак уездері Ресей құрамына өтіп кетті. Мұсылман-түріктер бұл аймақтың саны жағынан ең аз тұрғындары болды, бірақ 19 ғасыр бойы және 20 ғасырдың 1-ші ширегінде олардың үлесі бірте-бірте өсті. Сонда Осман империясынан тарайтын, Ахалцихе аймағынан шыққан түріктердің арғы аталары осы жерде мыңдаған жылдарға жуық өмір сүрді. Ал, осы пашалықты мекендеген Ахыска түріктері жергілікті шығыс-анатолийлік диалектімен байытылған түрік тілінде сөйлейтін түркілік этникалық топ болып табылады.

Қазан төңкерісінен кейін, 1921 ж. Москвадағы 16 наурыздағы Туркия мен Ресей арасындағы достық келісім шартқа сәйкес, бұл жерлер Грузия жеріне қарады.

Кеңес дәуірінде бұл жерлерден түріктерді ығыстыру шаралары жүргізіле бастады. Мысалы, Ахалкалаки және Борчалы аудандарының негізінде армяндардың тағы бір әкімшілік бірлігін құру жолындағы қозғалыстар пайда болды (Aydıngün, 2014) және Ахалкалаки және Ахалцихе аудандарына армяндарды көшіру жұмыстары жалғастырылды. Әртүрлі шаралардың жүргізілгеніне қарамастан, бұл аймақта кеңес өкіметінің орнауы негізінде түрік халқының өз әкімшілік басқару жүйесі пайда болды. Мектеп, клуб, техникумдар ашылды. Мектеп пен техникумдарда білім беру жүйесі әзірбайжан тілінде жүргізілді. Ұжымдастыру кезеңінде колхоздар ұйымдастырылды. Ахыскалық түріктер, барлық кеңес адамдары сияқты, «жарқын» болашағын құрып жатты.

Кеңестік дәуірдегі түркілік негізді әлсіруге бағытталған саяси-идеологиялық бағытқа орай, Ахыска пашалығы түріктерінің ұрпақтарына «месхеттік түріктер» немесе «месхеттер», «месхетиндер», «түрік месхеттер» деген атау таңылды. Бұл атау барлық ресми құжаттарда, тарихи зерттеулерде қолданылып, кеңестік дәуірде түрік-месхеттер деген халық атауы тарихи санаға енгізілді. Бірақ, КСРО ыдырап, егеменді мемлекеттердің пайда болуы тәуелсіз Қазақстанды мекендейтін түріктердің өздерінің тарихи-этникалық салт-санасына сай атауларын қайтаруға мүмкіндік берді.

Қазақстандағы түріктер өздерін месхет атауымен байланыстырғанын намыс көреді. Ахыска түріктеріміз деп өздерінің тарихи этникалық атауымен атауды дұрыс деп есептейді (Құдайбергенова, 2016). Ал, Месхетия-Джавахетия Грузиядағы географиялық жер атауы. Тіпті ол жер түрік-ахыскалардың Грузиядағы орналасқан жерін толықтай қамтымайды да. Қазақстандық түріктер өздеріне «месхеттер» деген атаудың қосылуын кеңестік биліктің түрік халқын ұлт есебінде жою мақсатында таққан шарасының бірі деп қабылдайды.

«Ахыска түріктері - бүгінгі Грузия жеріндегі Ахыска деп аталатын аймақта тұрған жергілікті халықтың атауы, - дейді «Ахыска турклері» этномәдени орталығы білім бөлімінің меңгерушісі Бегалы Байрам- Тарихи деректерде бабаларымыздың ол жаққа X ғ. төңірегінде Алтай өңірінен барғаны туралы 
айтылады. Осман империясының билеушісі Сүлеймен сұлтанның кезінде бұл өңір түрік мемлекетіне қараған. Орыс-түрік соғыстары кезінде үш-төрт мәрте қолдан-қолға өтіпті. 1829ж. келісімдер негізінде Ахыска өңіріндегі Ардаған, Пософ, Артвин, Чылдыр, Қарс және Сарықамыш қалалары Түркия қарамағында қалады. Ал қалған бөлігі (Аспинза, Ахыркәлак, Адыгюн, Богдановка аудандары) Ахыска ауданы аталып, Ресейдің құрамына алынады, кейін Грузин КСР-інің құрамына кіреді. Кеңестік кезеңде Түркия капиталистік мемлекет болғандықтан біздегі түрік ұлтының азаматтарына өз ұлтын атап көрсетуге рұқсат болмаған, сондықтан олардың көбі әзірбайжан болып жазылып кеткен»,-деп ол этностың саясат құрбанына айналғанын айтады (Құдайбергенова, 2016).

Сонымен, Қазақстандағы түріктер барлық ресми құжаттар мен зерттеулерде тәуелсіздік жылдарына дейін түрік-месхеттер деп аталып келді. Ел тәуелсіздік алғаннан кейін, түріктер өздерін «түрік-месхеттер» деп емес, «ахыска түріктері» немесе «түрік-ахыскалар» деп атай бастады.

Месхетия-Джавахетия Грузияның оңтүстік-батысындағы жазықтық болып табылады. Сол жер атауымен сол аумақтың 5 ауданын мекендеген түріктерді месхеттер деп атауды түріктердің ұлттық ерекшелігін жоймақшы болған кеңестік саясаттың нәтижесі деп есептейді қазақстандық түріктер. Өздерін Орта ғасырларда Грузия мен Түркияның шекаралас аймағында өмір сүрген Ахыска пашалығын мекендегендердің ұрпақтары деп есептейтін түріктер Грузияның Месхетия деген жер атауын өздеріне телігендерін қате деп санайды. Бұл түріктердің түпкі шыққан негізінің түркиялық екендігін тарихи санадан өшірмекші болған кеңестік саясаттың нәтижесі деп біледі. Сондықтан, Қазақстанның тәуелсіздік алуымен орай, қазақстандық түріктер өздеріне түрік-ахыскалар (ахыскалық түріктер) деген атауын қайтарып алды. Ол туралы арнайы шешім де қабылдады. Сондықтан, мақалада қазақстандық түріктерді «ахыскалық түріктер» деп атауды дұрыс деп таптық.

КСРО халқының лексиконынан «түрік» деген түсінікті жою науқаны 1924 ж. Сталин Грузияның оңтүстік аймағындағы түріктердің көшбасшысы Омар Фаикқа ұлтын ауыстырып, өзге абхаз, аджар сияқты ұлт өкілдеріне үлгі көрсетуді ұсынғанда басталған-ды. 1925 пен 1940 жж. аралығында бұл үдеріс түріктерге күштеп фрамилиясы мен ұлтын ауыстырту, іс жүзінде халықты басшысыз қалдыру, аз ғана сауаттыларының көзін жою, әзірбайжан, грузин болып жазылмағандарды туған атамекенінен жер аудару (депортациялау) түрінде жалғасты.

Соғыс алдындағы жылдардағы ахыскалықтардың өмірі жайлы Жамбыл облысының тұрғыны Яша Дадаев былайша еске түсіреді: «Біз Түркиямен Грузияның шекарасында тұрдық. Екі елдің арасында ешқандай күзет те, тартылған сым да жоқ еді. Осы екі елді біздің үйдің жанынан иіріліп ағып жатқан өзен бөліп тұратын. Сол өзеннің бойында үлкен гүл жайнаған бақша бар еді. Неше түрлі жеміс ағаштары: алма, алмұрт, шие, шабдалы бар еді. Жанжағындағы хош иісін бұрқыратқан әдемі гүлдерін айтсайшы! Алма, алмұрт, өрік тәрізді жеміс ағаштарының бұтақтары майысып, өнімдері «мені жеші!» деп уылжып пісіп тұратын. Бір ғажабы, мұндағы мұнтаздай тазалық бірден көңіліңді жадырататын. Бақшаны рахаттана аралап жемісіне тоятынбыз. Сыңсыған небір жеміс ағаштары. Бірден жұмаққа кіріп кеткендей боласың. Адам еңбекпен жұмақты да қолдан жасауға болады екен ғой дейтінбіз. Сол жерге ресми түрде шекара орнату үшін Сталин 30 әскерін жіберіп 5 күн бақшаны тырсылдата шауып, арамен кесіп тастады. Ауыл тұрғындары түбімен қопарылып жатқан бақшаны қимай тіпті көзіне жас алып жатты. Өзеннің арғы бетіндегі түрік 
әскерлері анау кесіп жатқан бақты көріп оқ жаудырмақ та болды. Алайда олардың бастықтары рұқсат бермеді, басу айтты. Сонымен сол бақшаның орнына шекара салынды. Шекара салынып жатқанда Лазарь Каганович, Климент Ворошилов, Лаврентий Берия, қалғандарын ұмытып тұрмын, жалпы алты адам келіп түрік шекарасын аралап көріп кетті. Климент Ворошилов айына екі рет келіп, қадағалап, өз көзімен көріп кететін. Сталин Германиядан 300 овчарка итін алдырыпты. Сталин келгенде жауынгерлер сол иттермен бірге қорғап жүретін. Оның жауынгерлері 6 сағаттан соң ауысып отыратын. Әр заставаға 5-10 ит берген. Сталин келген кезде иттердің шәуілдеген даусы шығатын» (Қалтөре, 2012).

Айта кету керек, соғыс алдындағы жылдары КСРО-ның алдымен батыс, сонан соң шығыс және оңтүстік шекарасында «тазалау» жүргізілген болатын. Ең алдымен Азербайжандағы кеңес-түрік және кеңес-иран шекарасын «сенімсіз азаматтардан» тазалау процесі жүреді. 1936 ж. 19 желтоқсандағы ХКК Қаулысы бойынша Оңтүстік Қазақстанға 400 отбасын көшіру көзделді. Солардың ішінде курд және армяндармен (хемшиндер - армяндардың мұсылмандары болу керек) бірге түріктер де болды. Кавказдан бұл кезде аз ғана адам көшірілді.

Тұтастай халықтарды жер аударулар 1936 ж. Батыс Украинаның шекаралық бөлігіндегі поляктар мен немістерді (Сталинские, 2005:69-70), 1937 ж. Азербайжан мен Армения курдтарын, сол жылы - Қиыр Шығыстан жер аударылған 180 мың кәрістерден басталған-ды. 1937 ж. соңында Оңтүстік Қазақстанға (Алматы және Оңтүстік Қазақстан облыстарының колхоздары мен совхоздарына) 1-2 мыңдай адамның жер аударылғаны туралы айтылады. Ішінде түріктер де бар (Сталинские, 2005:75-76). Соғыс алдындағы жылдары КСРО-ның оңтүстік батысындағы шекара аймағында тұрып жатқан, ықтияр хаты (белгілі бір жерде мекендеуге, жүріп-тұруға рұқсат беретін қағаз) бар түрік азаматтарын (негізінен Азербайжандағы түріктер) Орталық Азияға жер аударды. Олардың көшіп-қонуына бақылау қатаң болмағандықтан, өздері қалаған аудандарға көшіп кеткендері де болды (Сталинские, 2005:77). Бірақ, соғыс басталысымен барлық жер аударылғандардың құқықтық жағдайы бірдей қиындайды.

Ұлы Отан соғысы басталысымен қолына қару ұстай алатын барлық ер азаматтар майданға - неміс-фрашист басқыншыларымен шайқасуға шақырылды. Грузияның оңтүстігін мекен еткен 150 мың түріктің 40 мыңнан астамы Қызыл Әскер құрамына алынды. Бұл соғыста олар 26 мыңнан астам адамын жоғалтты. Өз Отанының еркіндігін қорғады, көптеген майдангерлермен бірге Месхетия түріктері де жауынгерлік орден және медальдармен марапатталды. Олардың ішінде сегіз ахыскалық түрік Кеңес Одағының Батыры атағын алып, ал үшеуі үшінші дәрежелі Даңқ орденімен марапатталған. Ахыскалық түріктерден шыққан Кеңес Одағының Батырлары: Мустафраев Бакир Дурсунович, Мурадов Бадир Мавлут оглы, Муртаз Каралиев, Мафиз Жулфаев, Ибрагим Тужигил, Убри Бадалов, Исмаил Каримов, Исмоил Тороманов.Бұл есімдер Кеңес Одағының Батырларының тізімі жарияланған кітаптан (Воениздат, 1988) алынды, Азшылық ұлттар ісі жөніндегі Европалық Орталықтың 2004 ж. маусым - 2006 ж. қыркүйек арасында жүргізген зерттеу жобасының нәтижесінде даярланған «Турки-месхетинцы: Интеграция. Репатриация. Эмиграция» атты кітапта (2007) жарияланды. Батырлардың көпшілігі қайтыс болғаннан кейін марапатталған (Турки, 2007). Сонымен бірге бұл тізім толық емес. Себебі, кітапта ұрыс даласында шайқасқан, құжаттарында өзбек, грузин, т.б. болып жазылып кеткендіктен белгісіз болып 
қалған Ахыскалық түріктерден шыққан батырлар туралы айтылмаған. Яғни бұл ахыскалық түріктерден шыққан басқа да батырлардың болу мүмкіндігіне назар аудартады. Ұлы Отан соғысына қатысып, Отанын қорғауға аттанған ахыскалық түріктердің тізімі де толықтырылып жатыр. Мысалы, Аспиндза ауданынан соғысқа қатысқан ахыскалық түріктер Иброхим Турки ағамыздың «Kismet (Тағдыр)» атты кітабында беріледі (Turki, 2014). Тарихын іздеген ахыскалық түріктер өз ауылдарынан шыққан майдангерлердің есімін анықтап, өз жерлестерінің түсін түгендеп, тарихи әділдікті қалпына келтіруге тырысуда. Нәтижесі де бар.

Ахыскалық түріктерден шыққан ер азаматтар өздерінің отан алдындағы борыштарын адал атқарып жатқанда, түрік-месхеттерді жер аудару мәселесі қызу қарастырылып жатты: Грузия үкіметі Одақтың Халық комиссарлар кеңесінің төрағасы Л. Берияға түрік тұрғындарды шекаралас аудандардан Грузияның түпкіріндегі аудандарға көшіру туралы ұсыныс енгізгенімен (К(б)П ОК Хатшысы К.Чарквани, ГСКР Халық комиссарлар кеңесінің төрағасы В.Бакрадзе (5 мамыр 1944 ж., №1500), Берия «КСРО-ның Грузин КСР аймағындағы мемлекеттік территориясын күзету жағдайын жақсарту» үшін «өз ойын» қосып, КСРО Ішкі істер халық комиссариаты Аджар АКСР-ның Ахальцих, Адиген, Ахалкалак, Богданов аудандарының бірнеше ауылдық советтерінен 16700 түрік, күрт, хемшин шаруашылықтарын Грузияның түпкіріндегі аудандарға емес, Орта Азияға көшіруді орынды санайды» деп хабарлап, Мемлекеттік Қорғаныс Комитетінің қаулысының жобасын даярлайды. Бұл «ісшара Грузия БК(б)П ОК және Грузин КСР Халық комиссарлар кеңесімен келісілді», - деп, Сталинге: «Сіздің шешіміңізді сұраймын - деп жазады. Осыған сәйкес Мемлекеттік Қорғаныс Комитеті 1944 ж. 31 шілдеде халықтардың тағдырын шешкен құпия қаулы қабылдайды.

Айта кету керек, түркі халықтарынан 1943 ж. қазан 1944 ж. мамыр аралығында Қазақстанға қарашайлар, ингуштер, қырым татарлары (1944 ж. 18 мамыр), балкарлар және т.б. жер аударылып келді. 1942-1943 жж. немістер қол астында болған қарашайларға: тәуелсіз ұлттық басқару жүйесін қалпына келтіру, діни бостандықпен бірге барлық бағытта халыққа толық еркіндік беру, колхоздар орнына жекеменшік жүйесін енгізу; екіге ажыраған қарашай-балқар халқын қайтадан біріктіруге уәде берген еді. 1943 ж. немістермен тіл табысты деген қарашайлар (Сталинские, 2005:390-392) - 11711 отбасы, 45529 адам; «Эльбрусты қорғай алмады және қарашайлармен біріккісі келді» деген желеумен балкарлар (4660 отбасы - 21150 адам) жер аударылды. Балкарлардың орындарына кабардиндерді көшірді (Сталинские, 2005:492]. Айта кету керек, көп ұзамай кабардиндер де тұтастай болмағанымен, жер аударылды.

Қырым татарларына тағылған айып салдарынан 1944 ж. мамырмаусымында 191014 қырым татарлары, олардан бірге 12422 қырымдық болгар, 15040 грек, 9621 армян, 1119 неміс, сондай-ақ, 3652 шетелдік азаматтар жер аударылды (Сталинские, 2005:492]. Бұлар Өзбекстанға, Башқұрт АКСР-не, Марий АКСР-не, Кемеров, Молотов, Свердлов, Киров облыстарына және Қазақстанның Гурьев облысына орналастырылды.

1944 ж. бастап Грузиядан курдтар, хемшидтер, азербайжандар көшірілді. 1944 ж. көктемінде шешен-ингуштер - 89901 отбасы, 406375 адам; Қырымнан 1268 отбасы, 4501 адам, 1944 ж. күзінде Грузиядан - 6296 отбасы, 27657 адам - барлығы 114484 отбасы - 507480 адам көшірілді (Асылбеков, 2005). Соның ішінде 1944 ж. қараша айында Грузиядан сатқындық жасауы мүмкін деген желеумен түрік-ахыскалар да Орталық Азияға жер аударылды. 
Қазақстандағы түріктер 14-15 қарашаны ұмытылмас күн ретінде қабылдайды. Бұл күннің этнос тарихындағы орны ерекше. Бұл ұлттың қайғысын еске түсіретін күн. Бұл Ахыска түріктерін өздерінің туған жерін, туған үйін, ертеден мекендеген отанын тастатып, топалаң тигендей етіп түгендеп, вагонға салып, жер аударған күн. Атамекенінен, ыстық ошағынан айырып, тұтастай ұлттың тағдырын күмән мен үрейге толтырған күн.

Ұлы Отан соғысы жылдарында көптеген халықтарды сатқындық жасады, тыңшылық жасайды және т.б. сылтау-себептермен арнайы қоныстарға жер аударды. 1944 ж. 14 қарашада Грузияның оңтүстік және оңтүстік-батыс аймақтарына қоныстанған түріктерді туған жерінен зорлықпен жер аудару басталды.

Бұл варварлық акцияға IIХК (НКВД) мен МҚХК (НКГБ) әскерлерінің 20 мың жауынгері мен офицерлері, тауар таситын пойыздың 57 эшалоны және адамдарды туған мекендерінен теміржол станцияларына дейін тасымалдау үшін 17 мың «студебеккер» жүк автомашиналары жұмылдырылды. ІІХК және МҚХК әскерлері Берияның жетекшілігімен еш жазығы жоқ халықты қаталдығы жағынан адамдыққа жат депортациялау акциясын жүргізе отырып өздерінің бар күшін қорғансыз әйелдерге, қарттар мен балаларға қарсы жұмсады. Әңгіме қысқа болды: «Сендерді көшіреді. Жиналыңдар! Жиналуға-екі сағат». Бар-жоғы үш-төрт күнде 18 қарашада депортацияның бұл кезеңі аяқталды.

Түріктерді жер аудару кезінде пайдаланған Боржоми-Вале темір жолын түріктердің өздеріне 1941-1944 жж. асығыс түрде салғызғанын айту керек. Яғни, Грузиядағы түріктерді жер аудару көптен бері дайындалған. Соғыс басталған кезде Боржомидан Валеге дейін 70 шақырымдық темір жол шеткері жатқан түріктер мекендеген аудандарды орталықпен байланыстыру үшін, шеткері аймақтан Грузияның орталығына барып-келіп, еркін жүріп тұру үшін ыңғайлы болу үшін салынып жатыр деген өтірікке сенген түрік халқы өз қолдарымен темір жол құрылысына көмектескен. Осы темір жолмен түріктерді өз отанынан айырып, күштеп жер аударды. Түріктерді жер аудару операциясына қатысқан солдаттар ішінде Қызыл әскер қатарында қызмет етіп жатқан жергілікті түріктердің де болғанын айту керек. Іштерінен қан жылаған жас солдаттар соғыстың қатал тәртібіне мойын сұнып, бұйрыққа қарсы келе алмады.

Түріктерді жер аудару саясатының алдында түріктер арасында басқа ұлт өкілдері болып жазылыңдар деген, намысқа тиетін үгіт-насихат жұмысы жүргізілді. Ахыскалық түріктерге грузин болып жазылыңдар деген кемсітушілік ұсыныстар айтылады. Отбасын, ұрпағын сақтап қалу үшін арасында грузин, азербайжан, түрікмен болып жазылғандар да кездесті. Бірақ, грузиндік зерттеушілерді өздері атап көрсеткендей, ер халық оған қарсы болды, өздерінің тегін, түп негізін, адалдығын сақтап қалды. Бұл туралы дәлел болар тарихи шындықты Грузия КН ОК-нің «Народное образование» газетінде шыққан және т.б. мақалаларынан кездестіруге болады (Народное, 1989).

Ескере кететін жайт, Ұлы Отан соғысы кезеңінде Грузия территориясы герман әскерінің басқыншылығына ұшырамаған еді. Сол себепті Месхетия жеріндегі түріктерді Германияға астыртын жәрдем берді деп айыптау қисынсыз еді. Шындығына келгенде, оларды жер аударудың себептері әлдеқайда тереңде жатты.

Екінші дүниежүзілік соғыс кезеңінде Түркия бейтараптық әрекетін жариялай отырып, гитлерлік Германиямен экономикалық қатынастарға қолдау көрсетті. Ұзақ уақытқа сақтықпен жүзеге асырылған кеңес-түрік 
қатынастарынан кейін КСРО Закавказье фрронтындағы Закавказье әскери округын қайта құрып, шекарада үлкен әскери күштерді ұстауға бекінді. Алайда, Антигитлерлік коалицияның жеңісіне сенім арта отырып, 1944 ж. Түркия үкіметі Германияға соғысын жариялауға мәжбүр болды. Сондықтан, КСРО халқына жасалатын әскери қоқан-лоққы саясатын Түркия күн тәртібінен алып тастады. Дегенмен, кеңес үкіметі ахыска түріктерінің Түркия аймағымен шекаралас жерлерінен алыстатуды, жер аударуды жалғастырды. Шынтуайттағанда, Сталин мен Берия Грузияның кейбір тұрғындарының шовинистік көзқарасын қолдай отырып, республиканың шұрайлы аймақтарынан түріктерді қуып шығып, мемлекеттің байырғы тұрғындары үшін «кеңістіктікті» кеңейтті. Сондықтан Месхет түріктері 1944 ж. қарашадағы депортация кезінде кеңес әскері тылындағы «бесінші колонна» болды деп айтылады.

Сталин мен Берия түріктерді Грузиядан жер аудару шараларын алдын ала дайындады. Мемлекеттің шығыс аймақтарына жаппай жер аудару кезінде Қазақстан, Өзбекстан және Қырғызстан өкіметі мен өлкелік партия басшыларына жер ауып келгендерді қабылдау мен орналастыруға дайындық туралы Грузиядан құпия нұсқаулар жіберілді. Алғашқыда «Грузиядан арнайы жер ауып келген» қандай халықтар екендігі нақты көрсетілмеді. Ақырында бұлар - Месхетиядан шыққан түріктер және күрд, ассирия, қарайымдар, т.б. «қажетсіз элементтер» екені анықталды. МҚК-ның 1944 ж. 31 шілдедегі қаулысына сәйкес, Қазақстан өкіметі Грузиядан ауып келген 40 мың адамды республикаға қоныстандыру туралы өте құпия құжат қабылдайды ${ }^{1}$. Бұған дейін қолданылған үлгі бойынша әрекет ете отырып, Сталин мен Берия МҚК-ның түріктер мен күрдтердің қоныс аударуы туралы соңғы қаулысын 1944 ж. 14 қараша күні қабылдайды. Сол күні кештен бастап түріктер мекендеген аймақтарды әскерлер қоршап, ешкімді кіргізбей не шығармай, 15-17 қараша арасында Грузияның Ахалцих, Адыген, Аспиндз, Ахалкалак және Богданов аудандарынан ресми құжаттарда «месхет түріктері» деп атаған ахыскалықтарды жинай бастайды. «Әскери жағдай» жарияланды.

Бұл кездегі халықтың көрген тауқыметі ұмытылмас. Бірі әкесінен, екіншісі шешесінен, үшіншісі бауырынан айырылып, бір-бірінен ажырап, бытырап кетеді. Сол кездің сұмдық суреттерін түрік азаматы Бәдір ақсақал былайша еске алады: «Ол кезде мен небәрі 17 жаста едім. Бір күні таңертең бәрімізді «жиналыс бар» деп қырманға жинады. Түсінбегеніміз, бізді сыртымыздан әскери адамдар қоршап алды. Олардың 50-ден астам пулеметі бар екенін әлі де ұмытпаппын. Бізді қырманға жинағандар: «Сендерге 24 сағат уақыт беріледі. Осы уақытта түгел жиналып бітіңдер. Орталық Азияға жібереміз. Жолға тек құжаттарыңды ғана алып шығыңдар. Қолдарыңдағы жүк 16 келіден аспауы керек» деді. Сонымен, 24 сағат уақыт қай жүгімізді жинап үлгеруге жетеді деп тұрғанда, 4 сағаттан соң қайта жинады. Бәрімізді жүк мәшинесіне қой тиегендей тиеп алды да жөнеп берді. Қайда барамыз, алдағы тағдырымыз не болады, біліп болмайды. Адамдарды асығыс жинағаны, машинаға топырлатып артқаны бар, кімнің кім, кімнің қайда екенін білуден қалдық. Жиналған, улап-шулаған адамдар, мұндайда ит үріп, сиыр мөңіреп кетеді екен ғой. Айналадағы у-шудан басымыз айналды. Артымызда маңырап қалып бара жатқан малға, пәлен жыл жылы ұямызға айналған баспанамызға қарай алмадық. Оған батылымыз да жетпеді» (Дәніқұлұлы, 2017).

17 қараша күні бір машинаға 7-8 отбасыдан, 1 вагонга 20-25 отбасыдан 81324 адам тиелген 25 эшелон Грузиядан жөнелтіледі. Үш-төрт күн ішінде 220

${ }^{1}$ ҚРОМА (Қазақстан Республикасы орталық мемлекеттік архиві). 1987 қ. 1 т. 16 іс. 8 п. 
ауылдың азан-қазаны шықты. Әр түрлі деректер бойынша сол күндері 90 мыңнан 116 мың, тіпті 125 мыңдай адам күштеп жер аударылды. Оның ішінде 115 мыңы ахыскалық түріктер, 7 мыңы күрдтер, 3 мыңы хемшиндер болды (Сталинские, 2005:528-533).

Қайғылы ауыртпалықты басынан өткізген этнос өкілдерінің саны туралы мәліметтер әр түрлі. Депортация тақырыбына қатысты мәліметтерді алғаш жариялаушылардың бірі Бугайдың еңбектерінде 17 қарашада сағат 16-ға қарай Грузиядан 25 эшалонмен 81324 жер аударылғандар жіберілді деп беріледі ${ }^{2}$. КСРО ІІХК ресми деректері бойынша, 1944 ж. 92307 адам күштеп жер аударылды, оның 18.923 адамы ерлер (қарттар мен балалар), 27399 әйелдер және 16 жасқа дейінгі балалар саны - 45085 адам. Алғашқы эшалондар Орталық Азия территориясына бір айдай жүріп жетті. Ай бойы товарлы поезбен қақаған қыста Орта Азияға қарай жер аударылған түріктер Өзбекстан, Қазақстан және Қырғыз республикаларына бөлініп түсірілді (Сталинские, 2005: 528-533).

«Теміржол вокзалына келген соң қойша иіріп, екі-үш күн ұстады. Ашық аспан астында. Сосын бәрімізді 60 жүк вагонына тиеді. Шындығында отырғызған жоқ, тиеді. Пойыз пысылдап жөнеп берді. Алғашқы екі-үш күнді нан, сусыз өткердік. Вагон есіктерін сыртынан мықтап құлыптап тастады. Пойыз әр жерге аялдайды, бірақ бізді одан түсірмейді, азық-түлік те бермейді. Күн болса қақап тұр. Жуынатын су болмаған соң адамдар биттеп кетеді екен. Оны да қойшы, вагонда дәретхана жоқ. Сосын вагонның бір шетін жамылғымен жауып қойдық. Әжетханамыз осы. Адамдар бөріткен, сүзекпен ауыра бастады. Вагоннан бір айға жуық уақыт түспедік. Осындай қиындықтан көп адамнан айырылдық. Көптеген отбасылар дымы қалмай өліп кетті, ошақтары сөнді. Жол-жөнекей ауырған адамдарды жинап әкететін болды. Олардың тағдырының немен тұйықталары жұмбақ. Бізде үлкен әпкем қатты ауырды. Тексерушілер келгенде әпкемді көріп қоймасын деп төсенішке орап, сыртынан тігіп қоятынмын. Сосын тексерушілерге «біздің вагонда ауру адамдар жоқ» деймін. Бірде өлген адамдарды арттағы бос вагондарға жинап жатыр деп естідік. Күндердің-күнінде біз мінген пойыз бір жерге келіп тоқтады. Бұл жерде сойқан соғыс болған екен. Зеңбірек оғынан, минадан, бомбадан ойдым-ойдым болып қалған жер көп. Өлген адамдарды сол жерге сұлатыпсұлатып тастай салды. Біз көрмеген қорлық қалмады. Небір қиын күндерді басымыздан өткердік.

Әр адамға күніне 200 грамм ғана нан береді. Осылайша, өліп-талып Алматы маңына келіп тоқтадық. Естерхан деген жерде өлілерді құдыққа тастады. Алматыдан да өтіп, алға кеттік. Ақыры Өзбекстанға аялдадық. Құдай сақтап, бізге сабыр, күш берді, шыдап бақтық. Өлгендерге салауат. Қалғандарымыз тырбанып тіршілік қамына кірістік» дейді қарт (Дәніқұлұлы, 2017).

Естеліктерге кезек берсек, бұл кезді Яша Дадаев ағамыз былай деп еске түсіреді: «18 күн дегенде 1-Алматыға келіп тоқтадық. Далада 35 градус суық. Қар борап тұр. Есімде шешендер мен ингуштар бізді күтіп алып көрпеге орап жылытты. Ол кезде Қазақстан Комунистік партиясының бірінші хатшысы Ж.Шаяхметов еді. Ол бірден мектептерді, балабақшаларды, ауруханаларды уақытша босатыңдар деп бұйрық беріп, бізді сол жерлерге орналастырды. Бізді балаларды (Мичуринге) Белбұлаққа апарды. Ата-анамыз, туғантуыстарымызды қайда алып кеткенін білмейміз. 15 күннен кейін қазақ

2 РФМА (Ресей Федерациясы мемлекеттік архиві), Р-9479 қор, 1 тізбе, 184 іс, 107 п.; 245 іс. 138 п 
үйлеріне бізді бөліп-бөліп тастады. Біз жер аударылып келгенде екі әпкем және анам бар еді. Біз екі ай коменданттық жүйенің тәртібінде болдық. Анам 1945 ж. аурудан көз жұмды. Ал, екі әпкем тұрмысқа шықты. Мен туысқан ағамның қолында қалдым. Соғыстың кезі еді. Су жоқ, қарды ерітіп соны кезекке тұрып іштік. Бірнеше күннен кейін екі шешен қызы келіп бізге бір бір стақаннан қуырылған жүгері әкеп таратып берді. Сол уақытта 2 адам аштықтан өліп кетті». Тағдардың қилы кезеңдерін бастан өткерген қария түрік ұлтынан болғанын жасырып туу куәлігіне азербайжан деп жазғызған екен (Қалтөре, 2012).

Грузин КСР-нан арнайы жер аударылғандар саны туралы нақты мәліметтер Қазақ КСР ІІХК-нің облыстар бойынша құрастырылған анықтамасында сақталған ${ }^{3}$.

Осы кезде 40 мыңнан аса ахыскалық түріктер Ұлы Отан соғысының майдандарында осы кеңестік отанын қорғап соғысып жатқанын еске түсірейік. Кеңес Армиясында әскери қызмет атқарудағы жер аударылған этнос өкілдерінен шыққан офицерлер мен солдаттарды әскерден босатып, халықтың негізгі бөлігі орналастырылған жаңа мекендерге жіберген оқиғалар да кездесті. Олар ІІХК-нің (НКВД) жергілікті органдарында тіркеуге алынғаннан кейін погонмен жүру, суық қару және ату құралдарын қолдану құқығынан айырылды. 12 жыл комендатура бақылауында жүрді

Соғыстан кейін тазалау үдерісі жалғастырылды. 1949 ж. «Қара теңіз жағалауы мен Кавказдағы Грузин КСР, Армян КСР мен Азербайжан КСР-ларын саяси сенімсіз элементтерден тазарту» үшін жүргізілген шаралар нәтижесінде түріктер мен гректер тағы депортацияланады. Олар Ресейдің Алтай өлкесіне, Томбы облысына және Қазақстанның Оңтүстік Қазақстан мен Жамбыл облыстарына жіберілді (Сталинские, 2005: 670-675).

Барлық жер аударылған түріктер «арнайы қоныстанушылар» деген құқықтық статусқа ие болды. 1956 ж. шейін құқығы шектелді, бақылау мен түртпектеу негізінде кемсіткен коменданттық жүйеге бағынды. «Арнайы қоныс аударушылар», көрші ауылдарға орналасқан туған-туыстарына бара алмады. Рұқсатсыз кетіп қалғандары айыппұл төлеп, тұтқындалды. Жүйені, тәртіпті бұзғандарын ұрып-соғып, сотқа тартты. Жер аударылғандар ішінде жаңа туған сәбилер де этникалық белгісіне орай кінәлі, «сатқын» деп танылды. Бұл вандализм осы уақытқа дейін жауапқа тартылмай келді.

Қарапайым халықты отанынан айырған бұл жер аудару жүз жиырма бес мыңдай адамды зар қақсатқан кезде, операцияның аяқталуына орай, IIXK мен МҚХК-ның көптеген қызметкерлері айрықша кызметі үшін арнайы ордендермен, медальдармен марапатталды. КСРО Ішкі істер халық комиссары Берияның Сталинге 1944 ж. 2 желтоқсанында берген ұсынысына сәйкес, 3 желтоқсанда М.И. Калинин «ІІХК мен МҚХК қызметкерлерін марапаттау туралы» Жарлыққа қол қояды. Үкіметтің арнайы тапсырмасын «табысты орындағаны үшін» I дәрежелі Отан соғысы орденімен сол операцияны басқарғандар: КСРО Мемлекеттік қауіпсіздік халық комиссарының орынбасары, 2-рангтегі қк (қауіпсіздік комитетінің- АҚ) комиссары Кобулов Б.3., ГКСР Мемлекеттік қауіпсіздік халық комиссары 3-рангтегі қк комиссары Рапава А.Н. және ГКСР Ішкі істер халық комиссары қк комиссары Каранадзе Г.Т. және т.б. 25 адам марапатталған. Сондай-ақ, II дәрежелі Отан соғысы орденімен 18 адам, Қызыл Жұлдыз орденімен - 85, «Ерлігі үшін» медалімен -67, «Әскери

${ }^{3}$ ҚРОМА. 1987 қ. 1 т. 16 іс. 8 п. 
еңбегі үшін» медалімен - 218, барлығы - 413 адам марапатталды. Жарғы «Правда» газетінде 4.12.1944 ж. жарияланды (Сталинские, 2005:535 с.).

1945 ж. жазында соғыс біткеннен кейін соғыстан зардап шеккен, жараланған мүгедек ардагерлер орала бастады. Олар жер аудару туралы мүлдем хабарлары болмады. Бұл орден мен медалдар таққан адамдар өз отандарына, туғандарына, жақындарына, бала-шағасына, әйеліне асықты. Бірақ оларды шекаралық пост күтіп тұрды. Ардагерлерге олардың отбасыларының жер аударылғандығы туралы айтып, тіпті олардың өздерінің бос қалған үйлеріне, аталарының мазарларына кіріп шығуларына мұрсат берілмеді.

Барлығын кері қайтарды. Ешқандай жерден өздерінің жақындары туралы ақпарат алу мүмкін болмады. Өз поселкаларына кіргізбей, адамдарды кабинеттерінен қуып шығып отырды. Олар Кеңес адамдары ретінде өз Отаны үшін, Сталин үшін батырлықпен соғысып, жан беріп еді. Ал енді отансыз қалды және ешкімге барып шағымдана алмады.

Соғысқа барып келген адамдар жақындарын іздей бастады. Одақ бойынша Өзбекстаннан, Қазақстаннан, Қырғызстаннан іздеу жүргізді. Жолы болғандар ғана бірнеше ай, жылдардан кейін бала-шаға, әйелін, жақындарын тауып жатты.

Жергілікті тұрғындар алғашында жер аударылып келгендерге өте сақтықпен қарады. Олар қатты қорықты, себебі халық арасында бұзақылар, адам жегіштер келді деген қауесет тараған болатын. Жергілікті билік ешқандай да кінәсіз тұтқындап отырды.

Жер аударылған халықтар көрген қиындықтарды айтып тауысу мүмкін емес. Қолдан келетін қайран жоқ, халықтың тіршілік үшін - аштықпен, ортаазия даласының аязымен, жергілікті тұрғындардың өшпенді қарым-қатынасымен күресі басталды. Өйткені партия қызметкерлері жер аударылғандарды қылмыскерлер, сатқындар, адам жегіштер деп жергілікті тұрғындардың санасына әбден сіңіріп қойған болатын.

Күн көру үшін жұмысқа араласты, тынымсыз еңбек етті. Еңбекқорлықтың арқасында айналасындағылардың құрметіне ие бола бастады. Ахыскалық түрік өкілдерінің арасынан еңбек екпінділері, социалистік еңбектің Ерлері шыға бастады.

Біраз уақыт өткеннен кейін жергілікті тұрғындардың жер аударушыларға деген қарым-қатынасы өзгере бастады. Түрік-ахыскалықтар жергілікті дәстүрді, тілді, әдет-ғұрыпты үйрене бастады. Колхоздар мен совхоздарға жұмысқа орналаса бастады. Балалар жергілікті тілде сабақ беретін мектептерге барып білім алды. Бұның бәрі жергілікті халықтар мен жер аударушылардың бір біріне деген жақындасуы мен қызығушылықтардың негізінде болды. Сақтық пен бөтендік жәйменен өзгеріп, келісім мен түсіністік қалыптаса бастады. Қырғыздар, өзбектер, қазақтар нан, сүт, киім беріп, шамалары келгенше біздің адамдарға көмек көрсетті.

Туған жерге қайтудан үміттерін үзген олар, жаңа қонысқа үйренісе бастады. Жұмысқа тұрып, шаруашылықпен айналысты. Елге оралу туралы ешқандай мүмкіндік болмады. Себебі Азкур ауылының шекарасында тұрған шекарашыларға бұйрық келген. Бұйрық бойынша түріктерді өз ауылдарына кіргізбеді. Көбісінде өзін куәландыратын құжаттары болмаған. Соғысқа қатысқан бұрынғы әскери қызметкерлерде туу туралы куәлік, әскери билет пен марапаттау құжаттарынан бөлек ештеме болмады. Олардың жүріп тұруына рұхсат болмады. Комендант рұхсатынсыз туыстарымен, таныстарымен 
кездесуге болмайтын. Егер мұндай жағдай тіркелсе оны қашқын деп есептеген.

1956 ж. дейін ахыскалық түріктерге мемлекеттік және әскери жұмыстарға шақырту берілмеген. Оларға екінші санаттағы адам ретінде қараған. Олар тек қара жұмыспен айналысты, балаларын жоғары оқу орындарына қабылдамаған. Хрущевтік жылымық кезеңі келді. Компартияның XX съезінен кейін, депортациялау актісі қылмыс деп танылды. «Арнайы қоныс аударылғандар» өмірінде өзгерістер басталды. КСРО Жоғарғы Кеңесінің 1956 ж. 28 сәуірдегі №135/142 жарлық бойынша ахыскалық түріктерге жасалған көптеген шектеулер алынып тасталынды. Оларға КСРО азаматтарының құқықтарына ие болу мүмкіндігі туды. Көптеген арнайы қоныстанушылар секілді, ахыскалық түріктерге қысым босаңсып, коменданттық тәртіп алынып тасталынды. Бірақ бұл Жарлықта «шектеулердің алынып тасталуы материалдық шығындарын қайтаруды қарастырмайды және олардың бұрынғы мекендеген отанына қайта оралуын қамтымайды» деп атап көрсетілді.

Содан бері ұзақ жылдар бойы ахыскалық түріктер кеңес өкіметінен өз құқықтарының толыққанды қалпына келуіне қол жеткізе алмады.

Қорыта айтқанда, түріктердің тірі қалуына бірден бір септескен қазақ халқының жер аударылғандарды жылы қабылдауы еді. Аса бір қиын соғыстан кейінгі жылдары оларға қолдарынан келгеннің бәрін жасап, мүмкіндігінше көмек көрсетті. Оларға баспана беріп, бір үзім нанды бөліп жеді. 1956 ж. олардан арнаулы жүріп-тұру бойынша шектеу алынған соң, жер аударылғандардың біразы Кавказға қайта оралды. Кеңестер Одағы тарағаннан кейін де депортацияланған халықтардың көбі өздерінің тарихи отанына орала бастады. Ал түріктер қайта алмады. Туған жері Грузия шекарасы олар үшін жабық еді. Қоныс аударушыларды қабылдап жатқан Түркияға да кетулеріне болар еді, бірақ ол жер Ахыска түріктерінің туған жері емес. Сөйтіп, түріктерді еркін де тыныш өмір сүретін мекеніне - Қазақстан жеріне тарихтың өзі қоныстандырды. Түріктердің көбі Қазақстанда біржолата орнығып қалды. Қазақстандық түріктердің тәуелсіздік алған Қазақстан жағдайында толыққанды құқықтарға ие болу мүмкіндігі туды. Грузияға барып келгені болмаса, қайтып кеткендері біренсаран. Қазақстандағы түріктердің жас буыны Түркияға барып, оқып, қалып қойғандары да бар. Бірақ, қазақстандық түріктердің басты ерекшелігі Қазақстан ахыска түріктері үшін - Кіші Отан.

«Ахыска» түрік этномәдени орталығы төрағасының орынбасары және осы орталықтың Алматы облысындағы бөлімшесінің төрағасы Асиев Шахисмаил Ахметұлымен сұхбат кезінде айтқаны бойынша: «Қазір Қазақстанда 199780 түрік тұрады. Одан бөлек 115 мың азербайжанның 80\% түріктер деп есептелінеді. Неге десеңіз кезінде азербайжан деп жазылғандардың қазіргі кезде түрік болып аталғысы келетініне байланысты. Мысалы, бір отбасында 2еуі түрік деп жазылып, 2-еуі азербайжан, не болмаса 2-еуі түрік, 1-еуі азербайжан болып жазылғандары бар. Тіпті паспортта түрік деп жазбағандықтан, ол графраны бос қалдырып, азербайжан деп жаздырмай жатқан жастар да кездеседі (Құдайбергенова, 2016).

Қазірде бірінің ұлты түрік, екіншісі - «әзірбайжан» болған бірге туған екі бауырды кездестіруге болады. Тоталитарлық билік адамдардың өткенін, түптамырын ұмытуы үшін бәрін жасады. Бірақ түріктердің ынтымағының арқасында олар өз мәдениеті мен ұлттық дәстүрлерін сақтай алды. 


\section{Әдебиеттер тізімі/ Список литературы}

1 Aydıngün, 2014 - Aydıngün A. Ahıska Türkleri. Ulusötesi bir topluluk. Ulusötesi aileler. Ankara: Ahmed Yesevi Üniversitesi, 2014. 200 s.

2 Aydingün, 1999 - Aydıngün A.B. A Deported Nationality: The Ahiska Turks// Perceptions Journal of International Affairs. December 1998 - February 1999. Volume III. Number 4. S. 1- 6.

3 Akiner, 2007 - Akiner Sh. Towards a Typology of Diasporas in Kazakhstan //Отан тарихы. 2007. №1. C. 13-59.

4 Алдажуманов, 1998 -Алдажуманов К.С., Алдажуманов Е.К. Депортация народов тоталитарного режима // Депортированные народы и проблема прав человека. Материалы семинара (Алматы, 12 июня 1997 г.) / Ред.: И. Трутанов и др. Алматы, 1998. С. 151-154.

5 Анес, 1998 - Анес Г. Выселение турок // Депортированные в Казахстан народы: время и судьбы. Алматы, 1998. С. 301-303.

6 Асылбеков, 2005 - Асылбеков М.Х., Құдайбергенова А.И. Қазақстан халқының әлеуметтікдемографиялық жағдайы (1939-1959 жж.): Алматы: Өркениет, 2005. 160 б.

7 Бугай, 1994 - Бугай Н. Турки из Месхетии: долгий путь реабилитации/Сост. Н. Бугай. М., 1994. $162 \mathrm{c.}$

8 Гаджиев, 1992 - Гаджиев А. На чужбине. Этническая культура ахалцихских (месхетинских) турок. Б., 1992.

9 Дәніқұлұлы, 2017 - Дәніқұлұлы С. Баба жұрт / http://www.altyn-orda.kz/kz/kazaksha-baba-zhurt/ қаралды: 2017 ж. 28 қаңтар.

10 Депортированные, 1998 - Депортированные в Казахстан народы: время и судьбы». Алматы: Арыс-Казахстан, 1998. 428 с.

11 Дымов, 1998 - Дымов О. Обиженных народов нет: [Турки-месхетинцы] // Депортированные в Казахстан народы: время и судьбы. Алматы, 1998. С. 397-398.

12 Закиев, 2011 - Закиев М.З. Глубокие этнические корни тюркских народов. Астана: Кантана Пресс, 2011.

13 Земсков, 1990 - Земсков В.Н. Спецпоселенцы (по документам НКВД и МВД СССР) // Социологическое исследование. 1990. № 11. С. 103-114

14 Ибрашева, 2014 - Ибрашева Ш.О. Қазақстандағы ахыска түріктері: Монография. Алматы: «Таугуль-Принт» баспасы, 2014 . 292 б.

15 Из истории, 2012 - Из истории депортаций в Казахстан. 1930-1935. Сборник документов. Алматы: LEM, 2012. 772 c.

16 Из истории, 2010 - Из истории депортации народов в Алматинскую область Казахстана / Ответ. составитель А.А. Муканова. Алматы, 2010. 472 с.

17 «Иосиф Сталин...», 1992 - «Иосиф Сталин - Лаврентию Берия: «Их надо депортировать...»: Документы, фракты и комментарии / Вступ. ст., и послесловие Н.Ф. Бугая. М.: Дружба народов, 1992. 286.

18 Khazanov, 1992 - Khazanov A.M. Meskhetian turks in search of self-identity// Central Asian Survey, Vol.11, № 1992. PP. 1-16. (3c.)

19 Курдаев, 1996- Курдаев Т.А. Книга народной памяти: (о турках). Алматы: Казахстан, 1996. 104 с.

20 Қалтөре, 2012 - Калтере Г.Наубетке ұшыраған қилы кезеңдерді еске алу / Ахыска. 14 сентября 2012. 8 c. http://www.ahiska-gazeta.com/cms/uploads/file_1347609998_151720910.pdf

21 Құдайбергенова, 2016 - Кудайбергенова А.И.Далалық жазбалар: Шахисмайл Ахметұлы Асиевпен; Қамбар Мұстафаев Маметұлымен; Ибрахим Түркимен және т.б. сұхбат. Алматы, 2016 ж. 22 Құдайбергенова, 2003 - Кудайбергенова А.И. Далалық жазбалардан. 2016, Сұхбат беруші Зофраров Ибрагим Хошидұлы.

23 Материалы, 2003 - Материалы по этнической истории тюркских народов Центральной Азии. Ташкент, 2003. 345 с.

24 Симоненко, 2010 - Симоненко В.А.Месхетинские турки: исторические условия двуязычия // Moodle.kubsu.ru; Турки-месхетинцы // Народы России. Атлас культур и религий.М.: Дизайн. Информация. Картография, 2010. 320с.

25 Симоненко, 2002 - Симоненко В.А.Месхетинские турки: историческая судьба и проблемы культурной адаптации / Диссертация. Краснодар: КубГУ, 2002

26 Velidi, 1981 - VelidiA.Z. Bügüngü Türkili (Türkistan) ve yakin tarihi. Istanbul: Aksıseda matbasi.1981.696 b.

27 «Народное...», 1989 - «Народное образование», 30 июля 1989 г.; Ш. Бадридзе. «Туркимесхетинцы»: как возникала проблема?// Газета «Вечерний Тбилиси», 25 июля 1989 г.

28 Панеш,1991 - Панеш Э.Х., Ермолов Л.Б. Месхетинские турки // Вопросы истории. 1991. № 910. С. 208-223.

29 Сталинские, 2005 - Сталинские депортации 1928-1953 гг. / сост. Яковлев А.Н., Поболь Н.Л., Полян П.М. М.: Международный фонд «Демократия», 2005. 904 с. 
30 Турки_2007 - Турки-месхетинцы: Интеграция. Репатриация. Эмиграция / под ред. Т.Триера и А.Ханжина. СПб.: Алатейа, 2007. 456 с.

31 Turki, 2014 -Turki I. Kismet: (Tarihi bilgi, deneme ve anilar) Судьба (Исторические справки, очерки, воспоминания). Шымкент: «Кітап» ЖШС, 2014. 200 б. (71-76).

32 Юнусов, 1999 - Юнусов А. Ахыскинские турки: дважды депортированный народ // Центральная Азия и Кавказ. 1999. № 6. С. 31-43.

\section{Referenses}

Aydıngün, 2014 - Aydıngün A. Ahıska Türkleri. Ulusötesi bir topluluk. Ulusötesi aileler. Ankara: Ahmed Yesevi Üniversitesi, 2014. $200 \mathrm{~s}$.

Aydıngün, 1999 - Aydingün A.B. A Deported Nationality: The Ahiska Turks// Perceptions Journal of International Affairs. December 1998 - February 1999. Volume III. Number 4. s. 1- 6.

Akiner, 2007 - Akiner Sh. Towards a Typology of Diasporas in Kazakhstan //Otan tarihy. 2007. №1. s. 13-59.

Aldazhumanov, 1997 - Aldazhumanov K.S., Aldazhumanov E.K. Deportaciya narodov totalitarnogo rezhima // Deportirovannye narody I problema prav cheloveka. Materialy seminara (Almaty, iuyn 12, 1997) / Ed.: I. Trutanov I drugie. Almaty, 1998. P. 151-154.(in Rus.)

Anes, 1998 - Anes G., Vyselenie turok // Deportirovannye v Kazakstan narody vremya I sud’by. Almaty, 1998. p. 301-303.(in Rus.)

Asylbekov, 2005 - Asylbekov M.Kh., Kudaybergenova A.I. Kazakhstan halkynyn aleumettikdemographic zhagdaiy (1939-1959): Almaty: Orkeniet, 2005. 160 s. (in Rus.)

Bugai, 1994 - Bugai. Turki iz Meshetii: dolgii put` reabilitacii / Comp. N. Bugai. M., 1994. 162 s.(in Rus.)

Gadzhiev, 1992 - Gadzhiev A. Na chujbine. Etnicheskaya kul tura axalcitskix (meshitinskih) turok. B., 1992. (in Rus.)

Danikululy, 2017 - Danikululy S. Baba zhurt / http://www.altyn-orda.kz/kz/kazaksha-baba-zhurt/: 2017. 28 January.

Departirovannye, 1998 - Departirovannye v Kazahstan narody: vremya i sud'by. Almaty: ArysKazakhstan, 1998. 428 s.(in Rus.)

Dymov, 1998 - Dymov O. Obizhennyh narodov net: [Turki-meshitinsy] // Departirovannye v Kazakhstan narody: vremya i sud by. Almaty: Arys-Kazakhstan, 1998. p. 397-398.(in Rus.)

Zakiev, 2011 - Zakiev M.Z. Glubokie etnicheskie korni turkskih narodov. Astana: Kantana Press, 2011.(in Rus.)

Zemskov, 1990 - Zemskov V.N. Specposekecy (po dokumentam NKVD i MVD SSSR) // Sociologicheskoe issledovanie. 1990. No. 11. P. 103-114. (in Rus.)

Ibrasheva, 2014 - Ibrasheva Sh.O. Kazakstandagy ahyska tyrikteri: Monograph. Almaty: «Taugul-Print" Baspasy, 2014. 292 s.(in Rus.)

Iz istorii, 2012 - Iz istorii deportacii v Kazakhstan. 1930-1935. Sbornik dokumentov. Almaty: LEM, 2012. 772 s.(in Rus.)

Iz istorii, 2010 - Iz istorii deportacii narodov v Almatinskuyu oblast` Kazakhstana / Otvet. sostavitel` A.A. Mukanova. Almaty, 2010, 472 s.(in Rus.)

Khazanov, 1992 - Khazanov A.M. Meskhetian turks in search of self-identity// Central Asian Survey, Vol.11, № 1992. PP. 1-16. (3c.)

Kurdaev, 1996 - Kurdaev T.A. Kniga narodnoi pamyati: (o turkah). Almaty: Kazakhstan, 1996. 104 s.

Kaltore, 2012 - Kaltore G. Naubetke ushyragan kily kezenderdi eske alu / Ahyska. sentyabrya 14, 2012. 8 s.http://www.ahiska-gazeta.com/cms/uploads/file_1347609998_151720910.pdf

Kudaibergenova, 2016 - Kudaibergenova A.I. Dalalyk zhazbalar: Shakhismail Akhmetuly Asiyevpen; Kambar Mustafayev Mametulymen; Ibrahim Türkimen zhane t.b. suhbat. Almaty, 2016 zh.

Kudaibergenova, 2016 - Kudaibergenova A.I. Dalalyk zhazbalardan. 2016, Suhbat berushi - Zofarov lbrahim Khoshiduly.

Materialy, 2003 - Materialy po etnicheskoi istorii turkskih narodov Central’noi Azii. Tashkent, 2003, 345 s. (in Rus.)

Joseph, 1992 - «Joseph Stalin - Lavrentiy Beria: «lh nado deportirovat`...": Dokumenty, facty I komentarii / Vstup. st., i posleslovie N.F. Bugaya. M.: Druzhba narodov, 1992. 286.(in Rus.)

Simonenko, 2010 - Simonenko B.A. Meshitinskie turki: istoricheskie usloviya dvuyazychiya // Moodle.kubsu.ru; Turki-meshetincy// Narody Rossii. Atlas kul'tur i religii. M.: Dizain. Informaciya. Kartografiya, 2010. 230 s.(in Rus.)

Simonenko, 2002 - Simonenko B.A. Meshitinskie turki: istoricheskayz sud'ba i problemy kul turnoi adaptacii/ Dissertaciya. Krasnodar: KubGU, 2002 (in Rus.)

Velidi, 1981 - Velidi A.Z. Bügüngü Türkili (Türkistan) ve yakin tarihi. Istanbul: Aksıseda matbasi.1981.696 b.

Narodnoe, 1989 - «Narodnoe obrazovanie», 30 iulya 1989 g.; SH. Badridze. «Turki-meshetincy»: kak voznikla problema?// Gazeta «Vechernii Tbilicii», 25 iulya1989 g.(in Rus.) 
Panesh, 1991 - Panesh E.H., Ermolov L.B. Meshetinskie turki // Voprosy istorii. 1991. № 9-10. S. 208223.(in Rus.)

Stalinskie, 2005 -Stalinskie deportacii 1928-1953 gg. / sost. Yakovlev A.N., PoBol` N.L., Polyan P.M. M.: Mezhdunarodnyi fond «Demokratiya», 2005. 904 s. (in Rus.)

Turki-meshetincy, 2007 - Turki-meshetincy: Integraciya. Repatriaciya. Emigraciya/ pod red. T.Triera i A.Hanjina. SPb.: Alateia, 2007. 456 s. s il.(in Rus.)

Turki, 2014 - Turki I. Kismet: (Tarihi bilgi, deneme ve anilar) Sud’ba (Istoricheskie spravki, ocherki, vospominaniya). Shymkent: «Kitap» ZHSHS, 2014. 200 b. (71-76).

Uynusov, 1999 - Uynusov A. Ahyskinskie turki: dvazhdy deportirovannyi narod // Central’naya Aziya i Kavkaz. 1999. № 6. S. 31-43.(in Rus.) 